\title{
The pseudopeptide HB-19 binds to cell surface nucleolin and inhibits angiogenesis
}

\author{
Vascular Cell 4:21 I DOI: 10.1186/2045-824X-4-21 I C Li et al.; licensee Publiverse Online S.R.L. \\ 2012 \\ Received: 24 Jul 2012 | Accepted: 30 Jul 2012 | Published: 24 Jul 2012 \\ Birmpas Charalampos, Briand Jean Paul, Courty Josẻ, Katsoris Panagiotis ${ }^{@}$ \\ ${ }^{+}$Contributed equally ${ }^{@}$ Corresponding author
}

\section{Abstract}

\section{Background}

Nucleolin is a protein over-expressed on the surface of tumor and endothelial cells. Recent studies have underlined the involvement of cell surface nucleolin in tumor growth and angiogenesis. This cell surface molecule serves as a receptor for various ligands implicated in pathophysiological processes such as growth factors, cell adhesion molecules like integrins, selectins or laminin-1, lipoproteins and viruses (HIV and coxsackie B). HB-19 is a synthetic multimeric pseudopeptide that binds cell surface expressed nucleolin and inhibits both tumor growth and angiogenesis.

\section{Methodology/principal findings}

In the present work, we further investigated the biological actions of pseudopeptide HB-19 on HUVECs. In a previous work, we have shown that HB-19 inhibits the in vivo angiogenesis on the chicken embryo CAM assay. We now provide evidence that HB-19 inhibits the in vitro adhesion, migration and proliferation of HUVECs without inducing their apoptosis. The above biological actions seem to be regulated by SRC, ERK1/2, AKT and FAK kinases as we found that HB-19 inhibits their activation in HUVECs. Matrix metalloproteinases (MMPs) play crucial roles in tumor growth and angiogenesis, so we investigated the effect of HB-19 on the expression of MMP-2 and we found that HB-19 downregulates MMP-2 in HUVECs. Finally, down regulation of nucleolin using siRNA confirmed the implication of nucleolin in the biological actions of these peptides.

\section{Conclusions/significance}

Taken together, these results indicate that HB-19 could constitute an interesting tool for tumor therapy strategy, targeting cell surface nucleolin.

\section{Introduction}

Nucleolin is a nucleolar protein ubiquitously expressed in exponentially growing eukaryotic cells. It was first described in 1973 as a protein involved in ribosome biogenesis and also in DNA and RNA metabolism [ 1]. More recently, nucleolin was shown to shuttle between cytoplasm and cell surface. In the cytoplasm, it provides a post-transcriptional regulation of mRNA and at the cell surface it serves as a low affinity receptor for several ligands such as growth factors [2,3]. Cell surface nucleolin was first described in hepatocarcinoma cells, suggesting that this molecule is involved in the growth of tumor cells [ 4].

Since this report, a growing body of evidence has pointed out the involvement of cell-surface expressed nucleolin in cell proliferation, and more specifically in tumor cell growth and angiogenesis. Surface 
nucleolin expression is constantly enhanced in various tumor cell lines and activated endothelial cells [ 2 , $5,6]$ and this expression is constantly induced in these cells [7]. The expression of nucleolin is enhanced on the surface of endothelial cells upon stimulation with the vascular endothelial growth factor (VEGF) [ 8]. The functional blockade or downregulation of surface nucleolin in endothelial cells inhibits their migration and prevents capillary-tubule formation [ 8]. Furthermore, several molecules related to cell proliferation or differentiation, have been reported as ligands for cell surface nucleolin. Among these molecules are the hepatocyte growth factor (HGF), the heparin affin regulatory peptide (HARP), midkine $(\mathrm{MK})$, the epithelial growth factor receptor (ErbB) and endostatin, which all play a significant role in tumor development and angiogenesis processes [ 9-12]. In addition, molecules involved in mechanisms regulating pericellular proteolysis, cell-surface adhesion and mitogenesis (such as urokinase) bind and are co-internalized with surface nucleolin [ 13, 14]. Other surface nucleolin binding proteins such as laminin-1, factor J, L- and P-selectins are involved in cell differentiation and regulate cell adhesion, leukocyte trafficking, inflammation and angiogenesis [ 15-19]. Cell surface nucleolin, as a novel target for anticancer therapy, was validated by using several molecules such as endostatin, the aptamer AS1411, the acharan sulfate and the homing tumor peptide F3 [ 20-22]. Furthermore, targeting nucleolin using a specific antibody causes activated endothelial cells apoptosis by decreasing the anti-apoptotic bcl $2 \mathrm{mRNA}$ in tumor vasculature [23].

In a previous study, we have reported that the nucleolin binding multivalent pseudopeptide HB-19 suppressed both tumor growth and angiogenesis [ 24]. HB-19 binds the RGG domain located in the Cterminal part of nucleolin and leads to its internalization [ 9, 24]. In vitro , HB-19 reduces tumor cell growth in soft agar assay in several carcinoma cell lines and impairs endothelial cells proliferation, migration and differentiation induced by VEGF [24]. These activities in both tumor and activated endothelial cells lead to tumor growth inhibition in breast carcinoma MDA-MB 231 and human melanoma MDA-MB 435 xenografts in athymic nude mice, without displaying any toxicity in normal tissues [ 24].

In this study, we have further investigated the anti-angiogenic activities and the mechanism of action of HB-19 on human umbilical vein endothelial cells (HUVECs).

\section{Materials and methods}

\section{Ethics statement}

For this study, we have obtained ethics approval from the ethics committee of University of Patras.

\section{Endothelial cell culture}

Human umbilical vein endothelial cells (HUVECs) were isolated from the umbilical cord vein by collagenase digestion as previously described [ 25] and used at passages $2-4$. The cells were grown as monolayers in medium M199 supplemented with $15 \%$ fetal bovine serum (FBS), $150 \mu \mathrm{g} / \mathrm{ml}$ of endothelial cell growth supplement, $5 \mathrm{U} / \mathrm{ml}$ heparin sodium, $100 \mathrm{U} / \mathrm{ml}$ penicillin-streptomycin and $50 \mu \mathrm{g} / \mathrm{ml}$ gentamycin. Cultures were maintained at $37^{\circ} \mathrm{C}, 5 \% \mathrm{CO}$ and $100 \%$ humidity.

\section{Cell proliferation assay}

An equal number of cultured HUVECs in medium containing 15\% FBS were left to adhere for $20 \mathrm{~h}$ in a cell culture microplate. They were then treated with various HB-19 concentrations and were allowed to proliferate for 3 days. The cell number was estimated by the crystal violet assay. Data are the mean \pm SEM of at least three independent experiments.

\section{Boyden chamber assay}

Migration assays were performed as previously described [26] in a 24-well microchemotaxis chamber (Costar, Avon, France), using untreated polycarbonate membranes with $8 \mu \mathrm{m}$ pores. HUVECs were harvested and resuspended at a concentration of $10^{5}$ cells $/ 0.1 \mathrm{ml}$ in the corresponding medium containing $0.25 \%$ bovine serum albumin (BSA) and HB-19. The bottom chamber was filled with $0.6 \mathrm{ml}$ of the corresponding medium containing $0.25 \%$ BSA. The upper chamber was loaded with $10^{5}$ cells and incubated for $4 \mathrm{~h}$ at $37^{\circ} \mathrm{C}$. After completion of the incubation, filters were fixed, non-migrated cells were scrapped off the upper side of the filter, and filters were stained with crystal violet. The number of migrated 
cells was quantified by counting the entire area of the filter using a grid and an Optech microscope at a 20x magnification.

\section{In vitro endothelial cell wound healing assay}

HUVECs were cultured in 6-well plates $2 \times 10^{5}$ cells/well as confluent monolayers. The monolayers were wounded in a line across the well with a $200 \mu \mathrm{l}$ standard pipette tip, washed twice with PBS to remove cell debris and incubated with increasing concentrations of HB-19 for $48 \mathrm{~h}$. The area of the initial wound was photographed using a charge-coupled device camera connected to an inverted microscope (Axiovert 35; Zeiss, Thornwood, NY). The wound healing effect was calculated in comparison with the area of the initial wound.

\section{Western blot analysis}

Cells were starved for $4 \mathrm{~h}$ and then incubated with various concentrations of HB-19 for $15 \mathrm{~min}$. Cells were subsequently washed twice with PBS and lysed in $250 \mu \mathrm{l} 2 \times$ SDS loading buffer under reducing conditions. Proteins were separated by SDS-PAGE and transferred to an Immobilon-P membrane for $3 \mathrm{~h}$ in $48 \mathrm{mM}$ Tris $\mathrm{pH} 8.3,39 \mathrm{mM}$ glycine, $0.037 \%$ SDS , and $20 \%$ methanol. The membrane was blocked in TBS containing $5 \%$ non-fat milk and $0.1 \%$ Tween 20 for $1 \mathrm{~h}$ at $37^{\circ} \mathrm{C}$. Membranes were incubated with primary antibody overnight at $4^{\circ} \mathrm{C}$ under continuous agitation, washed with PBS-Tween and incubated with the appropriate secondary antibody coupled to horseradish peroxidase. Protein bands were detected using the ChemiLucent Detection System Kit (Chemicon International Inc., CA) according to the manufacturer's instructions. Where indicated, blots were stripped in buffer containing $0.5 \mathrm{mM}$ Tris $\mathrm{HCl} \mathrm{pH} \mathrm{6.8,2 \%} \mathrm{SDS,} 100 \mathrm{mM} 2-$ mercaptoethanol for $30 \mathrm{~min}$ at $56^{\circ} \mathrm{C}$ and re probed. A quantitative estimation of band size and intensity was performed through analysis of digital images using the ImagePC image analysis software (Scion Corporation, Frederick, MD).

\section{Gelatin zymography}

Secreted metalloproteinases were detected and characterized by zymography. Conditioned media were obtained after an $8 \mathrm{~h}$ incubation of cells in serum-free media and then were loaded onto $10 \%$ SDS-PAGE gels that had been co-polymerized with $1 \mathrm{mg} / \mathrm{ml}$ gelatin. Electrophoresis was carried out under nonreducing conditions at $100 \mathrm{~V}$ for $2 \mathrm{~h}$ at $4^{\circ} \mathrm{C}$. Gels were washed once for $60 \mathrm{~min}$ in $2.5 \%$ Triton X-100 to remove SDS and incubated in zymogen activation buffer $\left(50 \mathrm{mM}\right.$ Tris- $\mathrm{HCl} \mathrm{pH} 7.6,10 \mathrm{mM} \mathrm{CaCl}{ }_{2}, 0.2 \mathrm{M}$ $\mathrm{NaCl}$ ) for $24 \mathrm{~h}$ at $37^{\circ} \mathrm{C}$. Gels were stained with $0.5 \%$ Coomassie blue in $30 \%$ methanol/10\% acetic acid for $30 \mathrm{~min}$ at room temperature and de-stained in $30 \%$ methanol/10\% acetic acid three times for $15 \mathrm{~min}$. The presence of metalloproteinases was indicated by an unstained (due to proteolysis) zone in the substrate. Both active forms and pro-enzymes are revealed by this technique, since exposure of pro-MMPs to SDS during SDS-PAGE leads to activation without proteolytic cleavage. The relative amounts of MMPs were quantified by NIH Image Analysis software. The normalization was based on the number of cells of each well (using the crystal violet method).

\section{Annexin $\mathrm{V}$ binding staining}

The analysis of annexin V binding was carried out with an Annexin V-FITC Detection Kit I (PharMingen, San Diego, CA) according to the manufacturer's instructions. An equal number of cultured HUVECs in medium containing $15 \%$ FBS were left to adhere for $20 \mathrm{~h}$ in a cell culture microplate. They were then treated with various HB-19 concentrations and collected after $24 \mathrm{~h}$, washed twice with cold PBS, centrifuged at $200 \mathrm{~g}$ for $5 \mathrm{~min}$ and resuspended in binding buffer at a concentration of $10^{6}$ cells per $\mathrm{ml} .100$ $\mu \mathrm{l}$ of the solution were transferred to a $5 \mathrm{ml}$ culture tube and $5 \mu \mathrm{l}$ of annexin V-FITC and $5 \mu \mathrm{l}$ of PI were added. Cells were gently vortexed and incubated for $15 \mathrm{~min}$ at room temperature in the dark. Finally, $400 \mu \mathrm{l}$ of binding buffer were added to each tube, and samples were analyzed by FACScan flow cytometer (Becton Dickinson). For each sample, 10,000 ungated events were acquired. PI (-)/annexin $(+)$ cells represent early apoptotic populations and PI $(+)$ /annexin $(+)$ cells represent late apoptotic populations.

\section{Crystal violet assay}

Adherent cells were fixed with methanol and stained with $0.5 \%$ crystal violet in $20 \%$ methanol for 20 min. After gentle rinsing with water, the retained dye was extracted with $30 \%$ acetic acid, and the absorbance was measured at $595 \mathrm{~nm}$. 


\section{Reverse transcriptase-polymerase chain reaction (RT-PCR) for nucleolin, MMP2, and GAPDH}

Total RNA was extracted using the Nucleospin RNA II kit (Macherey-Nagel, Germany) according to the manufacturer's instructions. The integrity of isolated RNA was examined by electrophoresis on a $1 \%$ agarose gel containing $0.5 \mathrm{mg} / \mathrm{ml}$ ethidium bromide. Specific primers were as follows:Nucleolin, $5^{\prime \prime}$ - TGCCAAGAAGACAGTTACACCA $-3^{\prime \prime}$ and

$5^{\prime \prime}$ - AGGAACAACTTTTGCAGCTTTC - 3"; MMP2,

$5^{\prime \prime}-$ ACAGTCCGCCAAATGAACC - $3^{\prime \prime}$ and

$5^{\prime \prime}$ - CCTGGGCAACAAATATGAGA $-3^{\prime \prime}$

GAPDH,

$5^{\prime \prime}$-CCACCCATGGCAAATTCCATGGCA-3" and $5^{\prime \prime}$ TCTAGACGGCAGGTCAGGTCCACC-3" .

The RT-PCR reactions were performed in a single step with $250 \mathrm{ng}$ of total RNA, using the Qiagen RT-PCR system. The RT-PCR products were subjected to electrophoresis on $1 \%$ agarose gel containing $0.5 \mathrm{mg} / \mathrm{ml}$ ethidium bromide, digitally photographed, and quantified using image analysis software (Scion Image PC, Scion Corporation, Frederick, MD).

\section{SiRNA transfection}

RNA oligonucleotide primers were obtained from Ambion Inc and the Lipofectamine RNAiMAX Transfection Agent was obtained from Invitrogen. The following sequences were used:

siRNA Nucleolin sense : $5^{\prime \prime}$-GGAUAGUUACUGACCGGGA-3";

siRNA Nucleolin antisense: $5^{\prime \prime}$-UCCCGGUCAGUAACUAUCC-3",

HUVECs were plated in 6 wells-plates and incubated for 24 hours at $37^{\circ} \mathrm{C}$. Cells were then transfected at a final concentration of 10nM siRNA using Lipofectamine RNAiMAX reagent (Invitrogen) according to the manufacturer's instructions.Transfection efficiency was evaluated using Silencer FAM Labelled GAPDH siRNA (Ambion). Negative control siRNAs from Ambion was also used.

\section{Materials}

Cell culture reagents were from BiochromKG (Seromed, Germany). All other reagents were purchased from Sigma-Aldrich. Monoclonal antibodies against pSRC (Tyr416), pFAK (Tyr925), pAKT (Ser473), pERK1/2 (Thr202/Tyr204), total SRC, total ERK1/2 and were purchased from Cell Signaling Technology. Polyclonal antibody against HSC70 and monoclonal antibody against NCL (nucleolin) were purchased from Santa Cruz Biotechnology, Inc.

\section{Peptide synthesis}

HB-19 was synthesized, as previously described, using the solid phase peptide methodology [ 8].

\section{Adhesion assay}

24-well culture plates were coated with $1 \% \mathrm{v} / \mathrm{v}$ gelatin for $20 \mathrm{~min}$ at $37^{0} \mathrm{C} .5 \times 10^{4}$ resuspended cells incubated in M199 medium with different concentrations of HB-19 for 30 min and then seeded. After a 30 min incubation period, unattached cells were removed by shaking the plates at 2,000 rpm for $10 \mathrm{sec}$, followed by three washes with PBS. The attached cells number was estimated by the crystal violet assay. Data are the mean \pm SEM of at least three independent experiments.

\section{Statistical analysis}

Comparisons of the mean values among groups were performed by means of ANOVA and unpaired Student $t$-test. Homogeneity of variances was tested by Levene's test. Each experiment included at least triplicate measurements for each condition tested. All results are expressed as mean \pm SE. from at least three independent experiments. Values of $\mathrm{p}$ less than 0.05 were accepted as significant $\left({ }^{*} \mathrm{p}<0.05,{ }^{* *} \mathrm{p}<0.01\right.$, $* * * \mathrm{p}<0.001)$.

\section{Results}


The effect of HB-19 on the adhesion of HUVECs was first investigated. As shown in Figure 1 A, HB-19 significantly inhibited the in vitro adhesion in a concentration-dependent manner, reaching a maximal effect at a concentration of $50 \mu \mathrm{M}$ yielding $40 \%$ inhibition compared to the control (Figure $1 \mathrm{~A}$ ). As cells will adhere if left for more than $6 \mathrm{~h}$, we investigated the effect of HB-19 on the proliferation of HUVECs. HB19 inhibited cell proliferation in a concentration dependent manner, having a maximal effect ( $41 \%$ inhibition relative to control) at a concentration of $50 \mu \mathrm{M}$ (Figure 1 B). We then investigated the effect of HB-19 on HUVEC migration, using Transwell assays. Similar to the effects on cell adhesion and proliferation, HB-19 inhibited migration in a concentration-dependent manner, with a maximal effect (61\% inhibition relative to control) observed at the concentration of $50 \mu \mathrm{M}$ (Figure 1 C). Furthermore, the effect of HB-19 has been studied in wound-closure assay. As shown in Figure 1 D and Additional file 1:, HB-19 inhibits HUVEC motility.

\section{Figure 1}

A

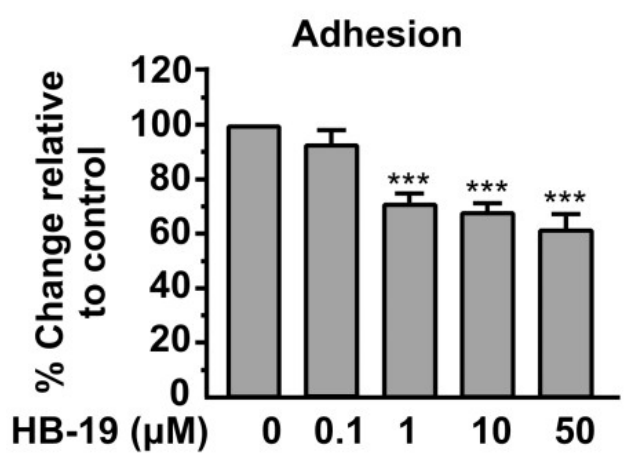

C

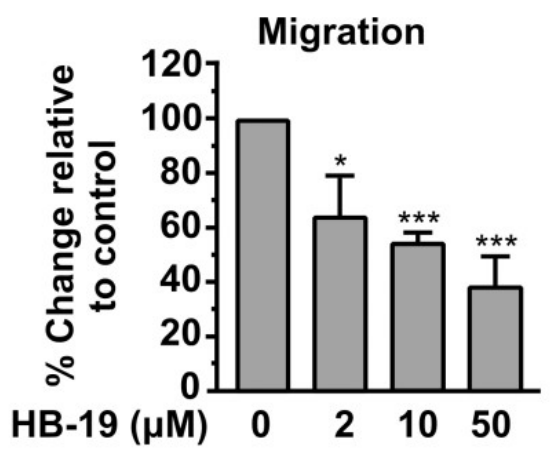

B

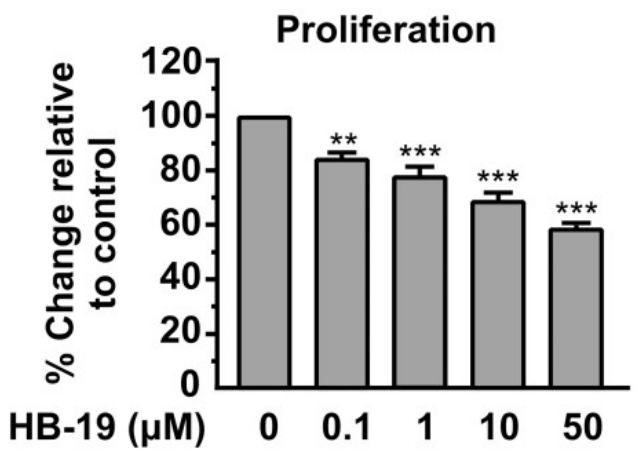

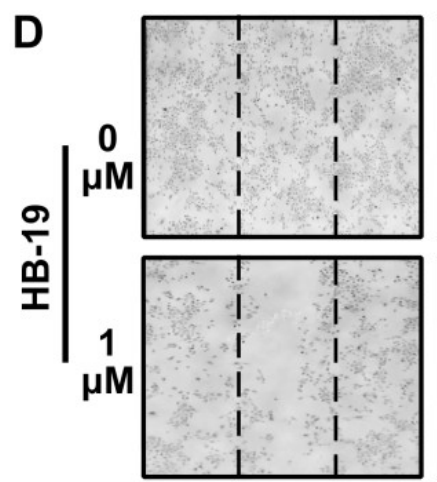

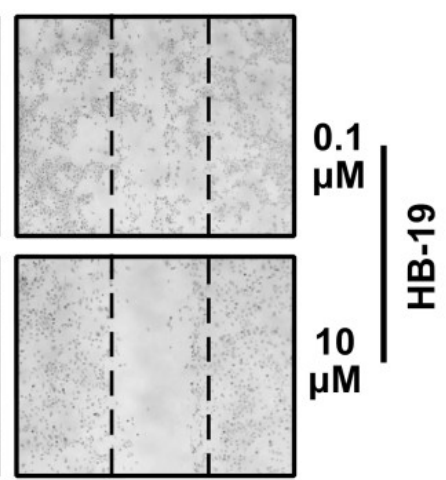

HB-19 inhibits the in vitro adhesion, proliferation, migration and motility of HUVECs.( A) Inhibition of HUVECs adhesion by HB-19. An equal number of HUVECs were incubated with increasing concentrations of HB-19 for 30 min before seeding. After a 45 min incubation period, adherent cells were measured by the crystal violet assay. Results are expressed as \% change relative to control and are mean values \pm SE from at least 3 independent experiments. ( B) Inhibition of HUVECs proliferation by HB-19. Cells were cultured for 3 days in presence of increasing concentrations of HB-19. Cell proliferation was quantified by crystal violet staining. Results are expressed as $\%$ change relative to control and are mean values \pm SE from at least 3 independent experiments. (C) Migration of cells through Transwell filters. The lower compartment of Transwell filters ( $8 \mu \mathrm{m}$ pores) was filled with growth media containing $0.25 \%$ BSA. An equal number of HUVECs was re suspended in growth medium containing $0.25 \%$ BSA and increasing concentrations of HB-19, and transferred into Transwell inserts. Cells that successfully migrated through the filter pores, were fixed, stained and quantified by counting the entire area of each filter. Results are expressed as \% change relative to control and are mean values $\pm \mathrm{SE}$ from at least 3 independent experiments. (D) Confluent cell monolayers were scratched and cells were left to heal the wound in the presence of increasing concentrations of HB-19. $48 \mathrm{~h}$ later the plates were photographed.

To confirm that HB-19 has a direct effect on adhesion and migration and secondarily on proliferation without affecting cell survival, a cytotoxic assay using HUVEC, treated or not with various concentrations of HB-19, has been performed. As shown in Figure 2, treatment of HUVEC with HB-19 for $24 \mathrm{~h}$ did not induce apoptosis (as well as in 48 and $72 \mathrm{~h}$, data not shown). Early apoptotic cells, which are in the beginning of apoptosis, are distinguished from already dead cells (late apoptosis). The data indicated that 
treatment with HB-19 in various concentrations for $24 \mathrm{~h}$ has no effect on the survival of HUVECs and confirmed that HB-19 has a direct effect on endothelial cells adhesion and migration and secondarily on their proliferation.

\section{Figure 2}

A

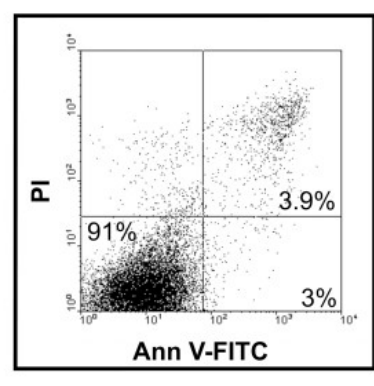

$0 \mu \mathrm{M} \mathrm{HB}-19$

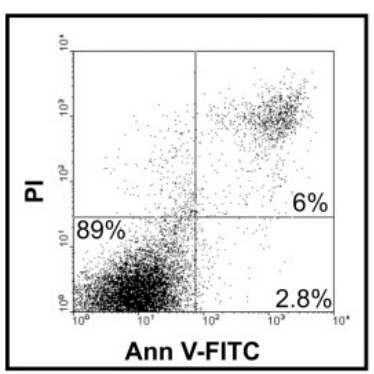

Ann V-FITC

$0.1 \mu \mathrm{M} \mathrm{HB}-19$

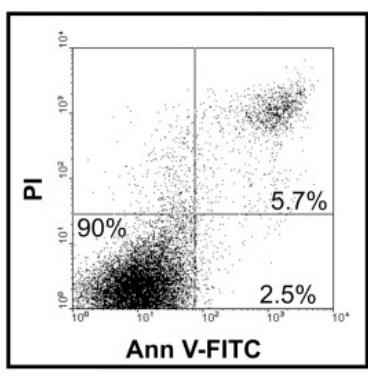

$1 \mu \mathrm{M} \mathrm{HB}-19$

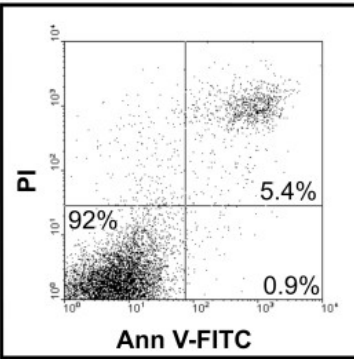

$10 \mu \mathrm{M} \mathrm{HB}-19$

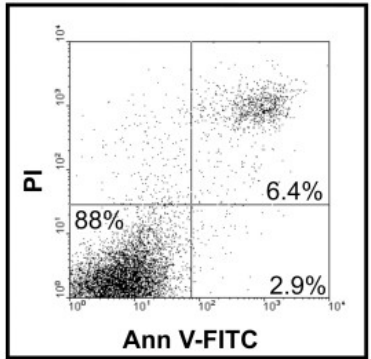

$50 \mu$ M HB-19
B

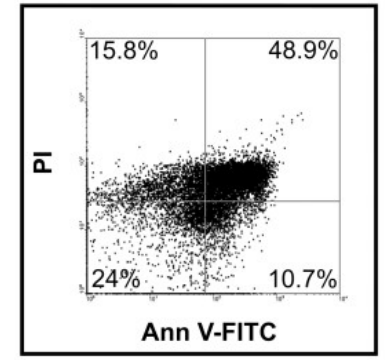

$\mathrm{H}_{2} \mathrm{O}_{2}$

C

Early Apoptosis

Late Apoptosis

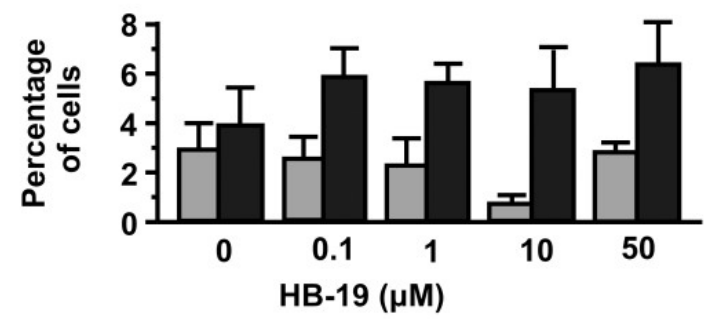

HB-19 does not induce apoptosis of HUVECs.( Aand C), endothelial cells were incubated with increasing concentrations of HB-19 and $24 \mathrm{~h}$ later the number of apoptotic cells was measured by FACS analysis. ( $\mathrm{B}), \mathrm{H}_{2} \mathrm{O}_{2}$ was used as positive control.

\section{HB-19 down-regulates MMP2 in HUVEC}

We next studied the effect of HB-19 on the activation of Matrix Metalloproteinases (MMPs) which are involved in the degradation of extracellular matrix, a prerequisite for cell migration. MMPs play a crucial role in angiogenesis, as they digest the ECM and facilitate the cell's migration. MMP2 is expressed in endothelial as well as in most cell types and is important for endothelial cell migration and vascular remodelling during angiogenesis [ 27,28]. It also facilitates the migration of tumor cells [29]. Matrix metalloproteinases (MMPs) are crucial in angiogenesis as cells produce them so as to digest ECM and facilitate their migration. Therefore, the effect of HB-19 on the activation of MMPs was investigated. The results showed that MMP2 activity was markedly reduced by $1 \mu \mathrm{M}$ of HB-19 (Figure $3 \mathrm{~A}$ ). We further demonstrated that HB-19 suppressed the expression of MMP2 mRNA as determined by RT-PCR (Figure $3 \mathrm{~B})$. The results indicated that both enzyme activity and the expression of MMP2 were inhibited by HB-19.

Figure 3 
A
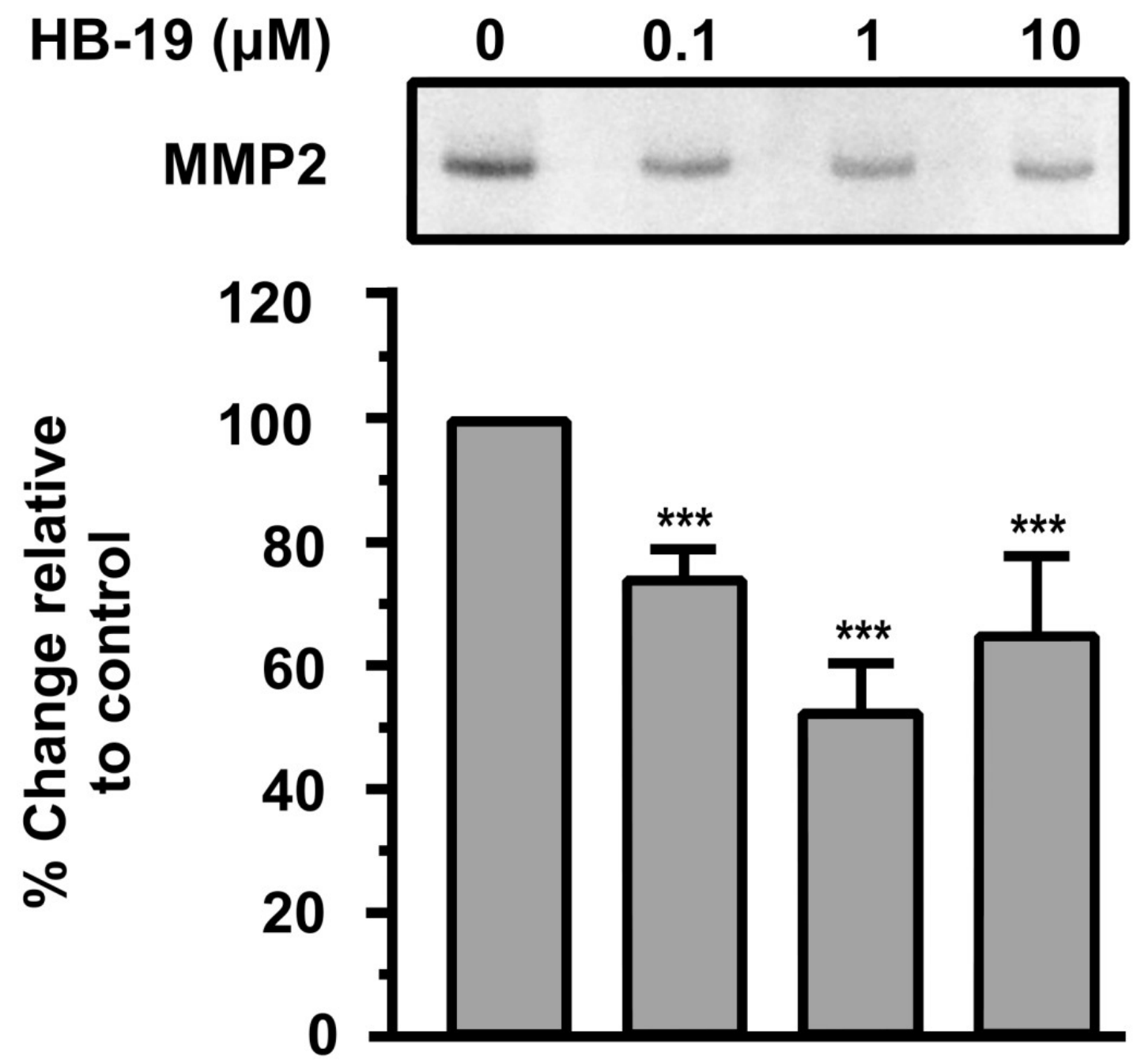

B

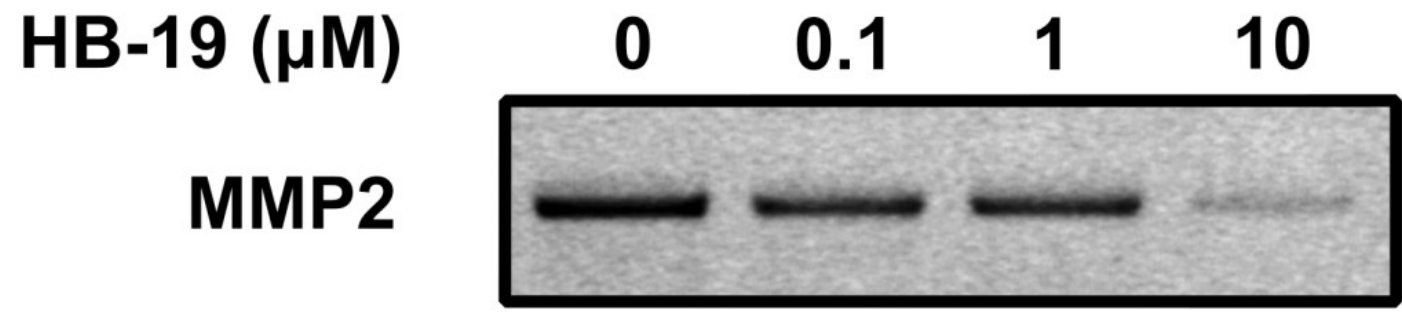

GAPDH

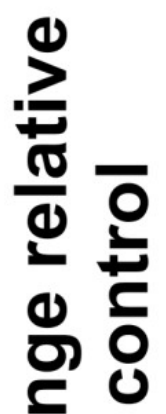

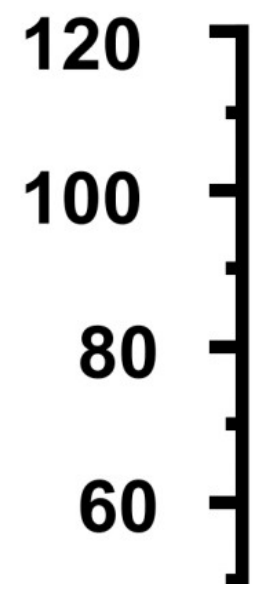




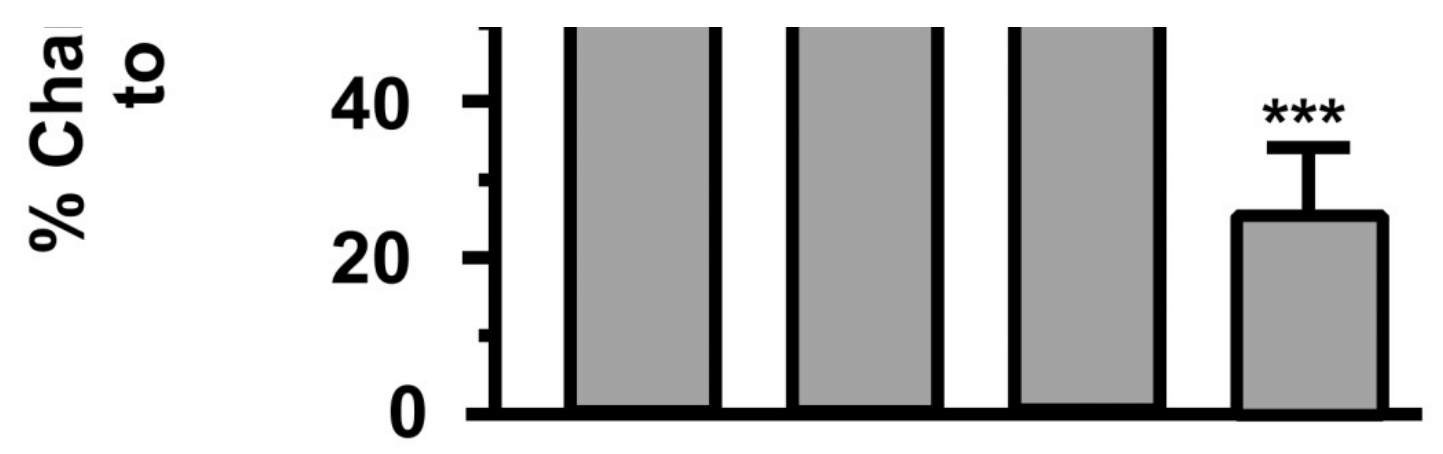

HB-19 down-regulates MMP2 in HUVECs.( A) Endothelial cells were cultured in a minimal medium with increasing concentrations of HB-19 and $8 \mathrm{~h}$ later the supernatants were analyzed for MMP2 activity by zymography. Results are expressed as \% change relative to control and are mean values \pm SE from at least 3 independent experiments. (B) Endothelial cells were incubated with increasing concentrations of HB-19 and $24 \mathrm{~h}$ later total RNA was extracted from the cells, RT-PCR reactions were performed using specific primers for MMP2 or GAPDH mRNAs, the PCR products were analyzed in agarose gels and quantified. Results are expressed as \% change relative to control and are mean values \pm $\mathrm{SE}$ from at least 3 independent experiments.

The results suggested that HB-19 and therefore nucleolin might affect the expression of genes involved in proteolytic activation.

\section{Inhibition of SRC, ERK1/2, FAK and AKT activation during HB-19 stimulation of HUVECs in vitro}

Several studies have indicated that the SRC, FAK, AKT and MAPKs are involved in the signal transduction that regulates angiogenesis [ 30,31$]$. Consequently, the effect of HB-19 on the phosphorylation status of SRC, FAK, AKT and ERK1/2 in HUVECs was investigated.

As shown in Figure 4A, HB-19 induced a decrease in SRC phosphorylation within 15 min and in a concentration dependent manner, with a maximal effect (80\% inhibition relative to control) at a concentration of $10 \mu \mathrm{M}$. We found that FAK phosphorylation was decreased 15 min after incubation of HUVECs with HB-19 in a concentration dependent manner. A significant decrease is observed at a concentration of $1 \mu \mathrm{M}$ yielding $51 \%$ inhibition as compared to the control. Similarly, we found that AKT phosphorylation was decreased 15 min after incubation of HUVECs with HB-19 in a concentration dependent manner with a maximal effect (75\% inhibition relative to control) at a concentration of $10 \mu \mathrm{M}$. As shown in Figure 4D, ERK1/2 were also inactivated after a15 min incubation with HB-19 in a concentration dependent manner, reaching a maximal effect (66\% inhibition relative to control) at a concentration of $10 \mu \mathrm{M}$.

\section{Figure 4}


A
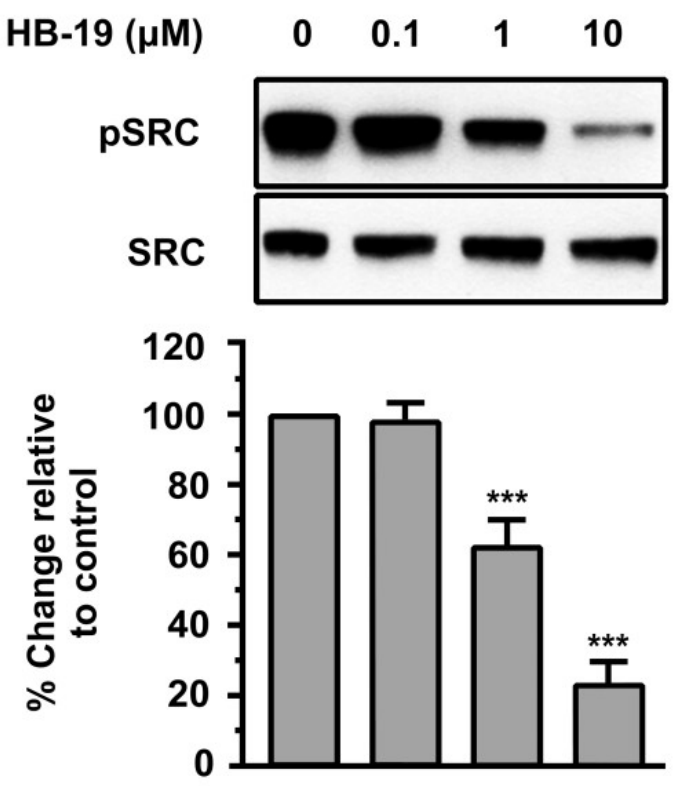

C
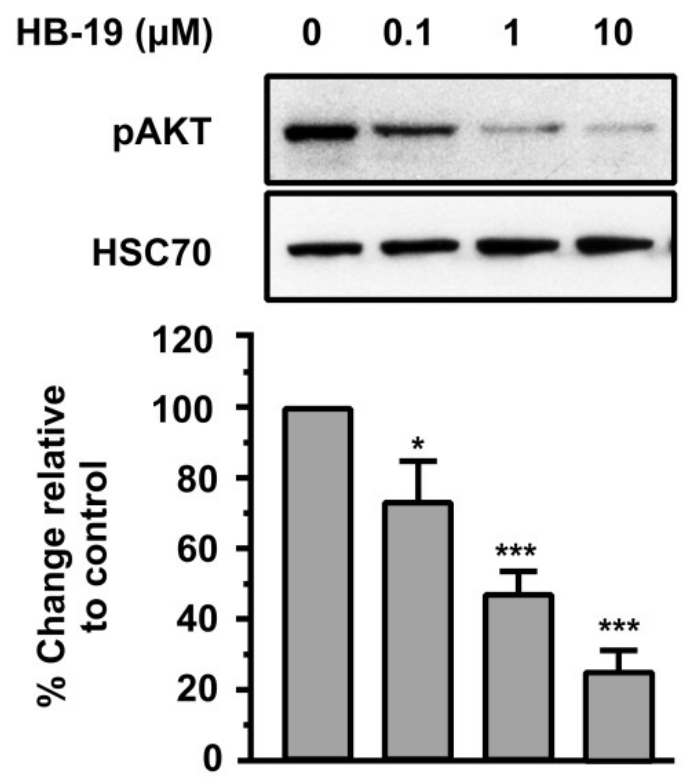

B

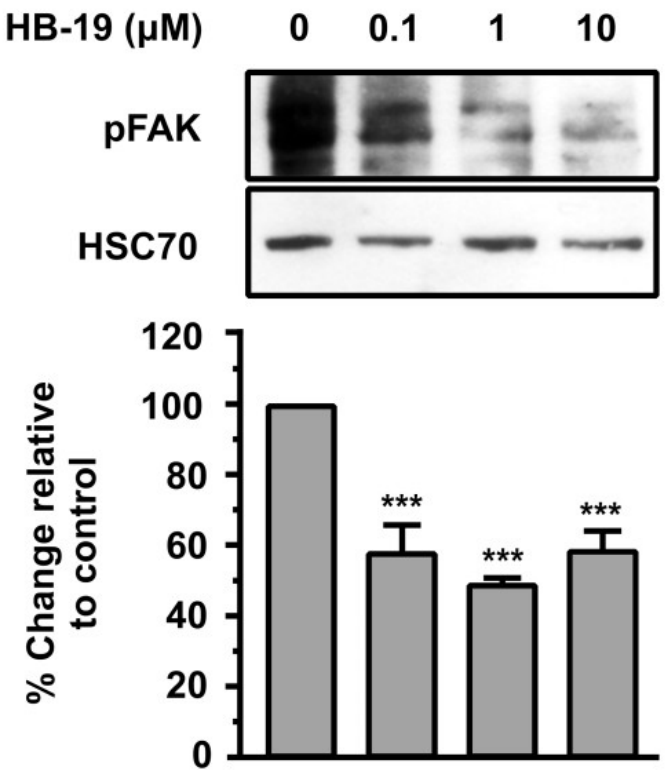

D

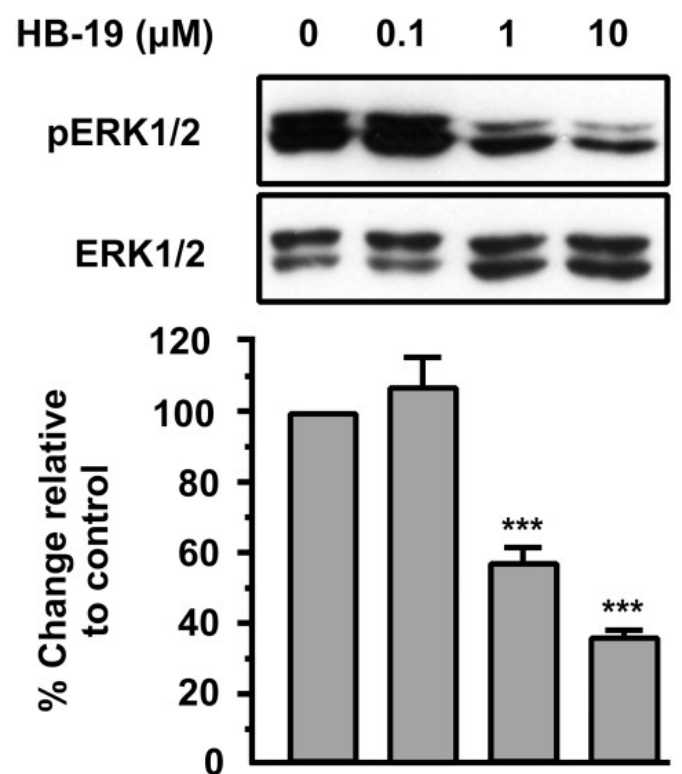

HB-19 signalling down-regulates pSRC, pFAK, pAKT and pERK1/2. Western blot analysis of phosphorylated SRC, FAK, AKT and ERK1/2, in cells stimulated by increasing concentrations of HB19 for 15 minutes. The blots were stripped and re probed for total SRC, HSC70, HSC70 and total ERK1/2 respectively. Results are expressed as \% change relative to the control and are mean values \pm SE from at least 3 independent experiments.

Taken together, these data indicate that HB-19 inhibits the phosphorylation of all of these kinases in a dosedependent manner (Figure 4 A, B, C and D). Results showed that the anti-angiogenic action of HB-19 might partly occur through a suppression of SRC, FAK, AKT and ERK pathways, but further research is needed in order to understand the mechanism of action of HB-19 and how it inhibits the activation of these signalling pathways.

\section{Down regulation of nucleolin expression inhibits adhesion and proliferation of HUVECs and blocks the inhibitory action of HB-19}

In order to confirm that HB-19 exerts the previously described biological actions mainly through nucleolin, as well as the involvement of cell-surface nucleolin in these effects, we transiently transfected HUVECs with a siRNA targeting the mRNA of nucleolin. In parallel, HUVECs were transiently transfected with a siRNA that does not target any mRNA (negative control) (data not shown). 
As shown in (Figure $5 \mathrm{~A}$ and $\mathrm{B}$ ), using specific siRNA targeting nucleolin mRNA reduces the levels of mRNA and protein up to $80 \%$ respectively.

Figure 5

A

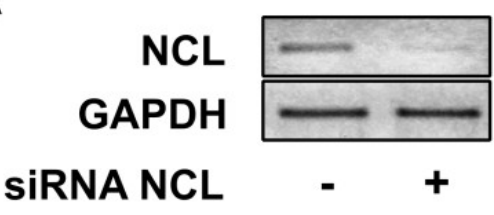

C

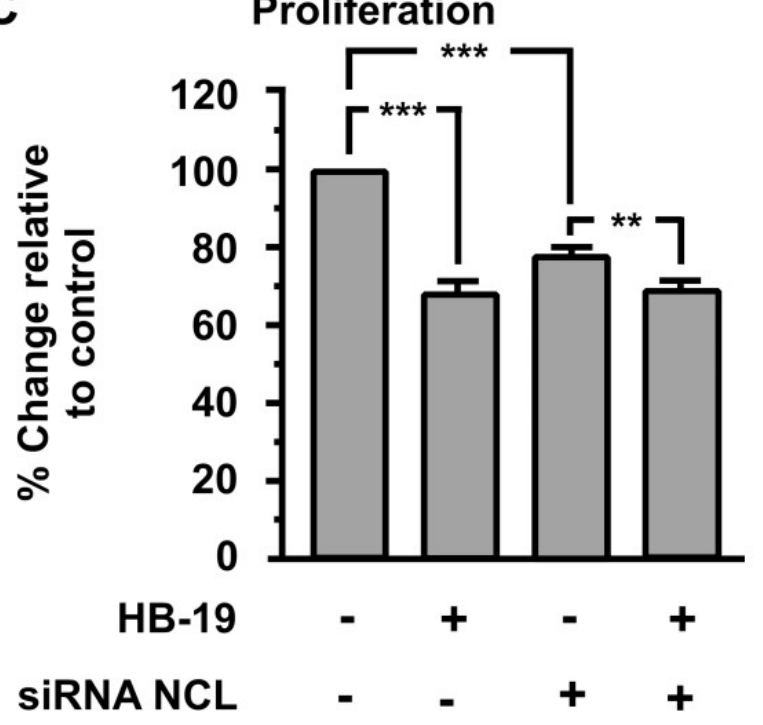

B

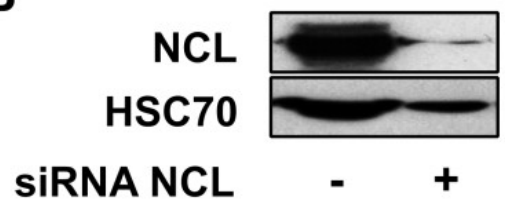

D

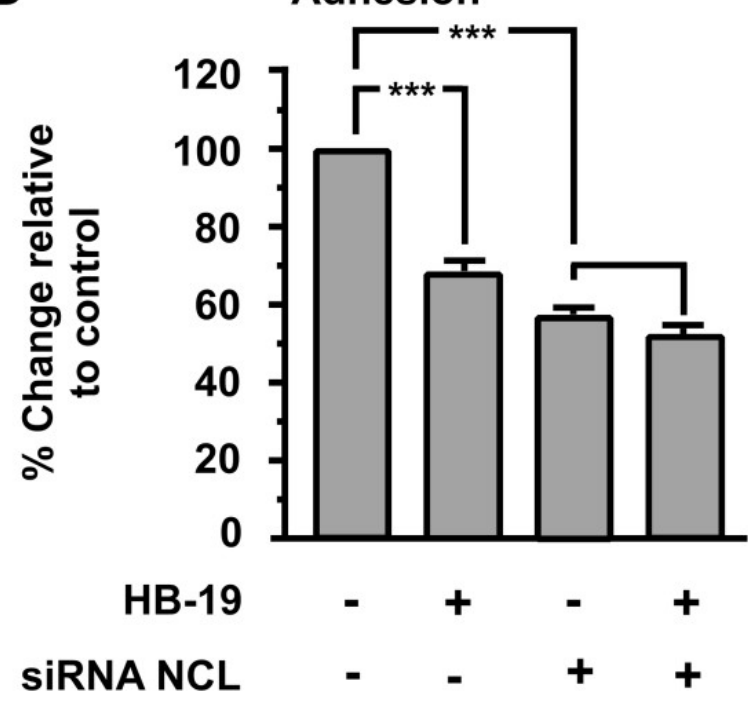

Effect of nucleolin (NCL) knockdown on HB-19 biological actions.Down-regulation of nucleolin (NCL) mRNA ( A) and protein ( B) using specific siRNA targeting nucleolin mRNA. Effect of HB-19 $(10 \mu \mathrm{M})$ on proliferation ( C) and adhesion ( D) of HUVECs. The last two bars of each diagram indicate HUVECs that were transiently transfected with siRNA targeting nucleolin (NCL). Results are expressed as \% change relative to control and are mean values \pm SE from at least 3 independent experiments.

As shown in (Figure 5C and D), NCL knockdown blocked the inhibitory effect of HB-19 in HUVECs proliferation and adhesion respectively. Moreover, the same experiment shows that nucleolin is a crucial factor in the proliferation and adhesion of HUVECs, since the down-regulation of nucleolin expression by itself results in the inhibition of proliferation and adhesion.

\section{Down regulation of nucleolin expression inhibits SRC and ERK1/2 activation in HUVECs and blocks the inhibitory action of HB-19}

Previous reports have shown that HB-19 interacts specifically with cell surface nucleolin [ 32].

To confirm that HB-19 signalling takes place mainly through nucleolin interaction, we tested the HB-19 effect on activation of SRC and ERK1/2 of transiently transfected HUVECs with siRNA for nucleolin mRNA. As shown in Figure 6A and B, the phosphorylation levels of SRC and ERK1/2 are induced on transiently transfected HUVECs compared with wild type cells, while nucleolin knockdown blocked HB19-induced SRC and ERK1/2 inactivation.

Figure 6 
A
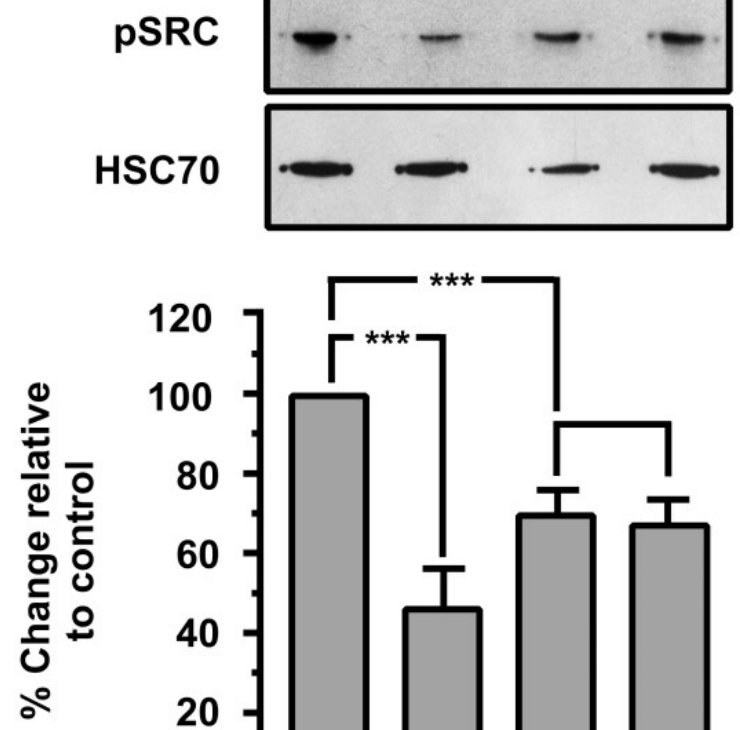

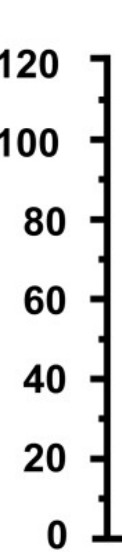

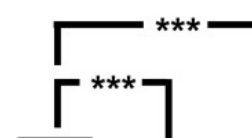
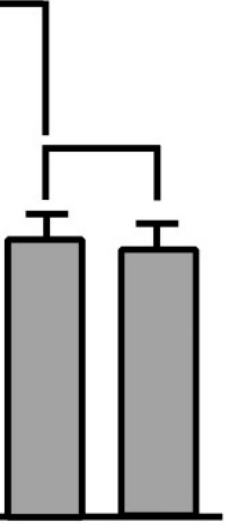

HB-19 SIRNA NCL

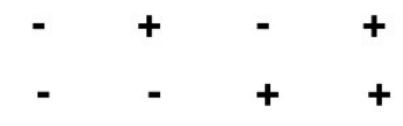

B

pERK1/2

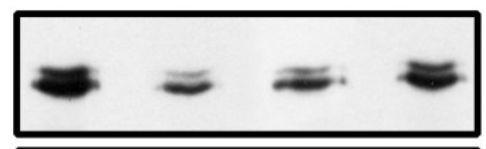

HSC70
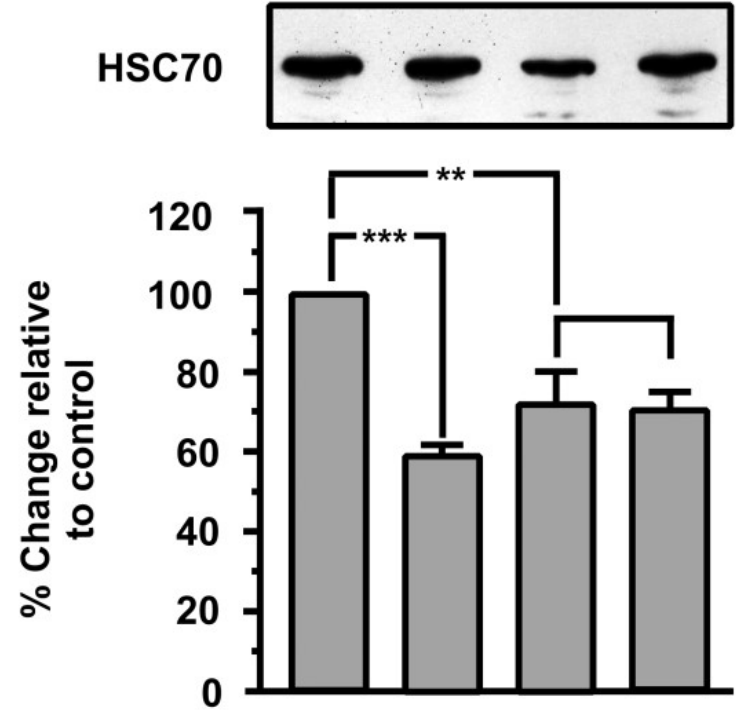

HB-19

SIRNA NCL

Effect of nucleolin (NCL) knockdown on HB-19-induced signal transduction.Western blot analysis of phosphorylated SRC and ERK1/2 in HUVECs stimulated with $10 \mu \mathrm{M}$ HB-19 for 15 minutes. The blots were stripped and re probed for HSC70. The last two bars of each diagram indicate HUVECs that were transiently transfected with siRNA targeting nucleolin. Results are expressed as \% change relative to control and are mean values $\pm \mathrm{SE}$ from at least 3 independent experiments.

Taken together, these results indicate that HB-19/nucleolin interaction affects various signal transduction pathways that reduce the phosphorylation levels of these signal transduction molecules, and are involved in the inhibition of cellular adhesion and proliferation.

\section{Discussion}

Several recent studies have described cell-surface nucleolin as a molecule involved in tumor growth and angiogenesis [ 2, 24, 33]. Targeting surface nucleoproteins like nucleolin with HB-19, is effective regarding the inhibition of tumour cell proliferation and impairment of angiogenesis [ 24, 33]. Therefore, functional blockade of surface nucleoproteins seems to result in an inhibition that is not due to a single growth factor implicated in carcinogenesis. Previous studies of our group have shown the dual action of HB-19 on tumour and endothelial cells, and have pointed out surface nucleoproteins as an important anticancer target [24]. The presence of nucleolin on the cell surface is the consequence of active translocation of cytoplasmic nucleolin to the surface upon stimulation of cell proliferation. Surface and cytoplasmic nucleolin are characterized by similar isoelectric points with $\mathrm{pI}$ values at about 4.5 , whereas nuclear nucleolin is composed of several subspecies with pI values between 4 and 6 [ 3, 32, 34]. These observations lead to the suggestion that the expression of surface nucleolin should be differentially regulated compared to its nuclear counterpart [7]. In support to this assumption, it was shown that surface nucleolin is $\mathrm{N}$-glycosylated and that this $\mathrm{N}$-glycosylation is required for the expression and function of nucleolin at the cell surface [ 35].

HB-19 binds the RGG domain at the C-terminal end of nucleolin, which is also the site for binding of RNA [ 36, 37], rDNA [ 38], a subset of ribosomal proteins [ 39], the urokinase-type plasminogen activator [ 14] and several growth factors [ 9-12]. The irreversible binding of HB-19 to this RGG domain could then prevent the proper functioning of surface nucleolin, thereby exerting its antagonistic action. In view of the implications of this in tumor growth and angiogenesis, as well as its capability to bind pathogens and diverse range of ligands including low density lipoproteins $[1,2,5]$, it is plausible to suggest that surface nucleoproteins could function as scavenger receptors [ 40]. Nucleolin was also shown to exist in a 500-kDa 
protein complex including several other proteins that are implicated in cell signaling, tumor cell adhesion, and other biological actions related to tumorigenesis and angiogenesis. Targeting surface nucleolin with HB-19 could change the organization of this complex leading to antitumoral and antiangiogenic effects. [ 33]

In this study, we sought to investigate the biological actions of HB-19 in endothelial HUVECs. Our results showed that HB-19 inhibits in vitro HUVECs adhesion, migration and motility in a concentration dependent manner (Figure 1 A, C and D). If left for more than $6 \mathrm{~h}$, HUVECs will adhere and migrate even in the presence of HB-19 (data not shown), therefore we investigated the effect of HB-19 in the proliferation of HUVECs showing that it is also inhibited, even if it is a secondary effect (Figure $1 \mathrm{~B}$ ). The inhibitory effect of HB-19 on angiogenesis [ 24] as well as on HUVECs migration and motility may be associated with down regulation of MMP2 [ 41, 42]. We found that both enzyme activity and expression of MMP2 were inhibited by HB-19 (Figure 3). Furthermore, we found that HB-19 treatment shows no toxicity in HUVECs in vitro, as HB-19 didn't induce apoptosis (Figure 2). HB-19 treatment is not toxic in various experimental models in vitro as well as in vivo. The lack of translocation of HB-19 to the nucleus probably accounts for its lack of toxicity [24,33].

As mentioned above, several molecules that are involved in tumor development and angiogenesis have been reported to be ligands for cell-surface nucleolin. HB-19 binds the C-terminal RGG domain of cellsurface expressed nucleolin and blocks its function as a receptor or binding molecule for various ligands [ $9,32,43,44]$. Additionally, the binding of an extracellular ligand to surface nucleolin has been reported to be involved in the activation of signaling pathways by promoting Ca2+ entry into cells [ 45].

In order to identify the signalling pathways that HB-19 affects and through which exerts its biological action, we investigated the effect of this peptide on well known angiogenic signalling pathways mediated by many of these ligands of nucleolin.We found that HB-19 inhibits the phosphorylation levels of SRC, FAK, AKT, and ERK1/2 in a concentration-dependent manner showing that the anti-angiogenic action of HB-19 might partly occur through suppressing SRC, FAK, AKT and ERK pathways.

Down regulating nucleolin, we found that the proliferation and adhesion of HUVECs was inhibited, highlighting the importance of nucleolin in these biological actions (Figure 5C and D). We studied the total effect of nucleolin without distinguishing between surface and nuclear nucleolin but we need to point out that the nuclear nucleolin has longer half life compared to the surface one. To confirm that our siRNA was specific for NCL, we examined the effect of siRNA on the expression of GAPDH mRNA as shown in Figure $5 \mathrm{~A}$ and other molecules such as tubulin (data not shown). The first comprehensive review of nucleolin was published more than 10 years ago and focused on the problem of ribosomal RNA transcription, maturation, and assembly [ 46], principally because the expression of this major nucleolar phosphoprotein was directly correlated with ribosomal DNA (rDNA) transcription [ 46- 50]. The focus of nucleolin research has since widened to include chromatin decondensation [ 51], cytoplasmic nucleolar transport of ribosomal components and preribosomal particles [47], and nucleogenesis [ 50]. In particular, nucleolin has been shown to be a component of B cell-specific transcription factor $[52,53]$, an autoantigen [ 54, 55], a DNA/RNA helicase [ 56], DNA-dependent ATPase [ 57], and a transcriptional repressor [ 58]. The protein therefore appears to be involved in fundamental aspects of transcriptional regulation, cell proliferation, and growth. Furthermore, nucleolin is required for a correct mitosis, controlled centrosome duplication [ 59] and plays a crucial role in the cell cycle [ 60].

The inhibitory effect of HB-19 on cellular proliferation and adhesion was almost completely blocked in the transfected HUVECs compared to the wild type (Figure 5C and D last two columns). Furthermore, the phosphorylation levels of SRC and ERK1/2 are induced on transiently transfected HUVECs compared with wild type cells (Figure 6, first and third columns), while nucleolin knockdown blocked HB-19-induced SRC and ERK1/2 inactivation (Figure 6 last two columns). In Figure 5B and 6 the reduction of HSC70 levels in siRNA transfected cells does not indicate secondary inhibitory effects of our siRNA on the expression of cellular proteins. We used HSC70 for western blot normalization and its reduced levels are a consequence of the reduced number of cells due to the inhibitory effect of NCL knock-down on cell proliferation. Taken together, these results indicate that the complex HB-19/nucleolin interaction triggers a signal transduction pathway that reduces the phosphorylation levels of these signal transduction molecules, and also that it inhibits cellular adhesion and proliferation. Down regulation of mRNA of NCL using siRNA is reported to reduce surface nucleolin [ 8]. Additionally, the expression of nucleolin on the surface of endothelial cells is due to the constant induction of nucleolin mRNA, as NCL mRNA and cell-surfaceNCL have half-life time of about 45'-90' whereas nuclear NCL has more than 24h [ 7]. Therefore, although we did not distinguish between surface and nuclear nucleolin, we can presume with relative safety that cell surface NCL levels were reduced in our experimental conditions. Consequently, we can hypothesize the 
involvement of surface NCL in HB-19 action and consider NCL to be the main molecule through which HB-19 exerts its action, knowing that there is more research to be done in order to extrapolate that the mechanism by which HB-19 exerts its action is through surface NCL.

In summary, in this study we shed light on the role of cell surface nucleoproteins in the regulation of their binding proteins signalling and activity in HUVECs. These results indicate that HB-19 and other pseudopeptides like NUCANT 6L could constitute an interesting tool for inhibiting angiogenesis. This possibility is reinforced by the fact that these multimeric pseudopeptides are synthetic molecules which lack in tissular toxicity and whose production can be easily upscaled and stable in serum, thus providing novel therapeutic opportunities in proliferative diseases.

Additional file 1: HB-19 inhibits in vitro wound healing of HUVECs. The scratched areas were quantified in three random fields in each treatment, and data were calculated from three independent experiments. Results are expressed as \% change relative to control and are mean values \pm SE from at least 3 independent experiments. (TIFF $57 \mathrm{~kb}$ ) (TIFF $57 \mathrm{~KB}$ )

\section{Declarations}

\section{Acknowledgments}

We gratefully thank Dr. Mavrommati Evangelia for providing us with umbilical cords for HUVECs isolation.

\section{Authors' original submitted files for images}

Below are the links to the authors' original submitted files for images.

Authors' original file for figure 1

Authors' original file for figure 2

Authors' original file for figure 3

Authors' original file for figure 4

Authors' original file for figure 5

Authors' original file for figure 6

\section{Competing interests}

The authors declare that they have no competing interests.

\section{Authors' contributions}

All authors participated in the design of the study. BC performed all experiments, performed the statistical analysis and drafted the manuscript. BJP constructed and provided the peptides. CJ helped to draft the manuscript. KP conceived of the study, participated in its design and coordination and helped to draft the manuscript. All authors read and approved the final manuscript.

\section{References}

1. Srivastava M, Pollard HB. Molecular dissection of nucleolin's role in growth and cell proliferation: new insights. FASEB J. 1999;13:1911-1922.

View Article Google Scholar

2. Storck S, Shukla M, Dimitrov S, Bouvet P. Functions of the histone chaperone nucleolin in diseases. Subcell Biochem. 2007;41:125-144.

View Article Google Scholar 
3. Hovanessian AG, Puvion-Dutilleul F, Nisole S, Svab J, Perret E, Deng JS, Krust B. The cellsurface-expressed nucleolin is associated with the actin cytoskeleton. Exp Cell Res. 2000;261:312-328.

View Article Google Scholar

4. Carpentier M, Morelle W, Coddeville B, Pons A, Masson M, Mazurier J, Legrand D. Nucleolin undergoes partial $\mathrm{N}$ - and $\mathrm{O}$-glycosylations in the extranuclear cell compartment. Biochemisty. 2005;44:5804-5814.

View Article Google Scholar

5. Semenkovich CF, Ostlund REJ, Olson MO, Yang JW. A protein partially expressed on the surface of HepG2 cells that binds lipoproteins specifically is nucleolin. Biochemistry. 1990;29:9708-9713.

View Article Google Scholar

6. Christian S Pilch J Akerman ME Porkka K Laakkonen P Ruoslahti E Nucleolin expressed at the cell surface is a marker of endothelial cells in angiogenic blood vessels J Cell Biol 2003 $163871878217367910.1083 /$ jcb.200304132

7. Hovanessian AG Soundaramourty C El Khoury D Nondier I Svab J Krust B Surface expressed nucleolin is constantly induced in tumor cells to mediate calcium-dependent ligand internalization PLoS One 20105 e157873009748 10.1371/journal.pone.0015787

8. Huang Y, Shi HHZ, Song X, Yuan S, Luo Y. The angiogenesis function of nucleolin is mediated by vascular endothelial growth factor and nonmuscle myosin. Blood. 2006;107:3564-3571.

View Article Google Scholar

9. Nisole S, Said EA, Mische C, Prevost MC, Krust B, Bouvet P, Bianco A, Briand JP, Hovanessian AG. The anti-HIV pentameric pseudopeptide HB-19 binds the C-terminal end of nucleolin and prevents anchorage of virus particles in the plasma membrane of target cells. J Biol Chem. 2002;277:20877-20886.

View Article Google Scholar

10. Said AE, Krust B, Nisole S, Briand JP, Hovanessian AG. The anti-HIV cytokine midkine binds the cell-surface-expressed nucleolin as a low affinity receptor. J Biol Chem. 2002;277:3749237502.

View Article Google Scholar

11. Said EA, Courty J, Svab J, Delbe' J, Krust B, Hovanessian AG. Pleiotrophin inhibits HIV infection by binding the cell surface expressed nucleolin. FEBS J. 2005;272:4646-4659. View Article Google Scholar

12. Legrand D, Vigie K, Said EA, Elass E, Masson M, Slomianny MC, Carpentier M, Briand JP, Mazurier J, Hovanessian AG. Surface nucleolin participates in both the binding and endocytosis of lactoferrin in target cells. Eur J Biochem. 2004;271:303-317.

View Article Google Scholar

13. Dumler I, Stepanova V, Jerke U, Mayboroda OA, Vogel F, Bouvet P, Tkachuk V, Haller H, Gulba DC. Urokinase-induced mitogenesis is mediated by casein kinase 2 and nucleolin. Curr Biol. 1999;9:1468-1476.

View Article Google Scholar

14. Stepanova V Lebedeva T Kuo A Yarovoi S Tkachuk S Zaitsev S Bdeir K Dumler I Marks MS Parfyonova Y Tkachuk VA Higazi AA Cines DB Nuclear translocation of urokinasetype plasminogen activator Blood 20081121001102435680 10.1182/blood-2007-07104455 
15. Kleinman HK, Weeks BS, Cannon FB, Sweeney TM, Sephel GC, Clement B, Zain M, Olson MO, Jucker M, Burrous BA. Identification of a 110-kDa nonintegrin cell surface laminin-binding protein which recognizes an A chain neurite-promoting peptide. Arch Biochem Biophys. 1991;290:320-325.

View Article Google Scholar

16. Harms G Kraft R Grelle G Volz B Dernedde J Tauber R Identification of nucleolin as a new L-selectin ligand Biochem J 20013605315381222254 10.1042/bj3600531

17. Larrucea S, Gonza_lez-Rubio C, Cambronero R, Ballou B, Bonay P, Lopez-Granados E, Bouvet P, Fontán G, Fresno M, López-Trascasa M. Cellular adhesion mediated by factor J, a complement inhibitor. Evidence for nucleolin involvement. J Biol Chem. 1998;273:31718-31725.

View Article Google Scholar

18. Reyes-Reyes EM Akiyama SK Cell-surface nucleolin is a signal transducing P-selectin binding protein for human colon carcinoma cells Exp Cell Res 2008314221222232504360 10.1016/j.yexcr.2008.03.016

19. Turck N, Lefebvre O, Gross I, Gendry P, Kedinger M, Simon-Assmann P, Launay JF. Effect of laminin-1 on intestinal cell differentiation involves inhibition of nuclear nucleolin. J Cell Physiol. 2006;206:545-555.

View Article Google Scholar

20. Bates PJ Laber DA Miller DM Thomas SD Trent JO Discovery and development of the Grich oligonucleotide AS1411 as a novel treatment for cancer Exp Mol Pathol 200986151 1642716701 10.1016/j.yexmp.2009.01.004

21. Drecoll E Gaertner FC Miederer M Blechert B Vallon M Müller JM Alke A Seidl C Bruchertseifer F Morgenstern A Senekowitsch-Schmidtke R Essler M Treatment of peritoneal carcinomatosis by targeted delivery of the radio-labeled tumor homing peptide biDTPA-[F3]2 into the nucleus of tumor cells PLoS One 20094 e57152682652 10.1371/journal.pone. 0005715

22. Shi H, Huang Y, Zhou H, Song X, Yuan S, Fu Y, Luo Y. Nucleolin is a receptor that mediates antiangiogenic and antitumor activity of endostatin. Blood. 2007;110:2899-2906.

View Article Google Scholar

23. Fogal V, Sugahara KN, Ruoslahti E, Christian S. Cell surface nucleolin antagonist causes endothelial cell apoptosis and normalization of tumor vasculature. Angiogenesis. 2009;12:91100 .

View Article Google Scholar

24. Destouches D El Khoury D Hamma-Kourbali Y Krust B Albanese P Katsoris P Guichard G Briand JP Courty J Hovanessian AG Suppression of tumor growth and angiogenesis by a specific antagonist of the cell-surface expressed nucleolin PLoS One 20083 e25182424174 10.1371/journal.pone.0002518

25. Jaffe EA Nachman RL Becker CG Minick CR Culture of human endothelial cells derived from umbilical veins. Identification by morphologic and immunologic criteria J Clin Invest $1973522745275630254210.1172 /$ JCI107470

26. Polykratis A, Katsoris P, Courty J, Papadimitriou E. Characterization of heparin affin regulatory peptide signaling in human endothelial cells. J Biol Chem. 2005;280:22454-22461.

View Article Google Scholar

27. Haas TL. Endothelial cell regulation of matrix metalloproteinases. Can J Physiol Pharmacol. 2005;83:1-7. 
28. Sluijter JP, de Kleijn DP, Pasterkamp G. Vascular remodeling and protease inhibition-bench to bedside. Cardiovasc Res. 2006;69:595-603.

View Article Google Scholar

29. Deryugina EI, Quigley JP. Matrix metalloproteinases and tumor metastasis. Cancer Metastasis Rev. 2006;25:9-34.

View Article Google Scholar

30. Cross M, Dixelius J, Matsumoto T, Claesson-Welsh L. . Trends Biochem Sci. 2003;28:488-494. View Article Google Scholar

31. Zhao X Guan JL Focal adhesion kinase and its signaling pathways in cell migration and angiogenesis Adv Drug Deliv Rev 2011636106153132829 10.1016/j.addr.2010.11.001

32. Nisole S, Krust B, Callebaut C, Guichard G, Muller S, Briand JP, Hovanessian AG. The anti-HIV pseudopeptide HB-19 forms a complex with the cell-surface-expressed nucleolin independent of heparan sulfate proteoglycans. J Biol Chem. 1999;274:27875-27884.

View Article Google Scholar

33. Krust B El Khoury D Nondier I Soundaramourty C Hovanessian AG Targeting surface nucleolin with multivalent HB-19 and related Nucant pseudopeptides results in distinct inhibitory mechanisms depending on the malignant tumor cell type BMC Cancer 201111 3333199867 10.1186/1471-2407-11-333

34. Nisole S, Krust B, Hovanessian AG. Anchorage of HIV on permissive cells leads to coaggregation of viral particles with surface nucleolin at membrane raft microdomains. Exp Cell Res. 2002;276:155-173.

View Article Google Scholar

35. Losfeld ME, Leroy A, Coddeville B, Carpentier M, Mazurier J, Legrand D. N-Glycosylation influences the structure and self-association abilities of recombinant nucleolin. FEBS J. 2011;278:2552-2564.

View Article Google Scholar

36. Ghisolfi L, Joseph G, Amalric F, Erard M. The glycine-rich domain of nucleolin has an unusual supersecondary structure responsible for its RNAHelix- destabilizing properties. J Biol Chem. 1992;267:2955-2959.

View Article Google Scholar

37. Ghisolfi-Nieto L, Joseph G, Puvion-Dutilleul F, Amalric F, Bouvet P. Nucleolin is a sequencespecific RNA-binding protein: characterization of targets on pre-ribosomal RNA. J Mol Biol. 1996;260:34-53.

View Article Google Scholar

38. Hanakahi LA, Sun H, Maizels N. High affinity interactions of nucleolin with G-G-paired rDNA. J Biol Chem. 1999;274:15908-15912.

View Article Google Scholar

39. Bouvet P, Diaz J-J, Kindbeiter K, Madjar J-J, Amalric F. Nucleolin interacts with several ribosomal proteins through its RGG domain. J Biol Chem. 1998;273:19025-19029.

View Article Google Scholar

40. Pluddemann A, Neyen C, Gordon S. Macrophage scavenger receptor and host-derived ligands. Methods. 2007;43:207-217.

View Article Google Scholar 
41. El Khoury D, Destouches D, Lengagne R, Krust B, Hamma-Kourbali Y, Garcette M, Niro S, Kato M, Briand JP, Courty J, Hovanessian AG, Prévost-Blondel A. Targeting surface nucleolin with a multivalent pseudopeptide delays development of spontaneous melanoma in RET transgenic mice. BMC Cancer. 2012;24:325-.

View Article Google Scholar

42. Krust B, El Khoury D, Soundaramourty C, Nondier I, Hovanessian AG. Suppression of tumorigenicity of rhabdoid tumor derived G401 cells by the multivalent HB-19 pseudopeptide that targets surface nucleolin. Biochimie. 2011;93:426-433.

View Article Google Scholar

43. Callebaut C, Blanco J, Benkirane N, Krust B, Jacotot E, Guichard G, Seddiki N, Svab J, Dam E, Muller S, Briand JP, Hovanessian AG. Identification of V3 loop-binding proteins as potential receptors implicated in the binding of HIV particles to CD4+ cells. J Biol Chem. 1998;273:21988-21997.

View Article Google Scholar

44. Sinclair JF, O'Brien AD. Cell surface-localized nucleolin is a eukaryotic receptor for the adhesin intimin-gamma of enterohemorrhagic Escherichia coli O157:H7. J Biol Chem. 2002;277:2876-2885.

View Article Google Scholar

45. Losfeld ME, Khoury DE, Mariot P, Carpentier M, Krust B, Briand JP, Mazurier J, Hovanessian AG, Legrand $\mathrm{D}$. The cell surface expressed nucleolin is a glycoprotein that triggers calcium entry into mammalian cells. Exp Cell Res. 2009;315:357-369.

View Article Google Scholar

46. Jordon G. At the heart of the nucleolus. Nature. 1987;329:489-490.

View Article Google Scholar

47. Herrera AH, Olson MOJ. Association of protein C23 with rapidly labeled nucleolar RNA. Biochemistry. 1986;25:6258-6264.

View Article Google Scholar

48. Borer RA, Lehner CF, Eppenberger HM, Nigg EA. Major nucleolar proteins shuttle between nucleus and cytoplasm. Cell. 1989;56:379-390.

View Article Google Scholar

49. Bouche G Gas N Prats H Baldin V Tauber JP Teissie J Amalric F Basic fibroblast growth factor enters the nucleolus and stimulates the transcription of ribosomal genes in ABAE cells undergoing Go-G1 transition Proc Natl Acad Sci USA 19878467706774299166 10.1073/pnas.84.19.6770

50. Caizergues-Ferrer M, Mariottini P, Curie C, Lapeyre B, Gas N, Amalric F, Amaldi F. Nucleolin from Xenopus laevis: cDNA cloning and expression during development. Genes Dev. 1989;3:324-333.

View Article Google Scholar

51. Erard M, Lakhdar-Ghazal F, Amalric F. Repeat peptide motifs which contain beta-turns and modulate DNA condensation into chromatin. Eur J Biochem. 1990;191:19-26.

View Article Google Scholar

52. Hanakahi LA, Dempsey LA, Li MJ, Maizels N. Nucleolin is one component of the B-cell specific transcription factor and switch region binding protein, LR1. Proc NatI Acad Sci USA. 1997;94:3605-3610.

View Article Google Scholar 
53. Borggrefe T, WabI M, Akhmedov AT, Jessberger R. A B-cell-specific DNA recombination complex. J Biol Chem. 1998;273:17025-17035.

View Article Google Scholar

54. Minota S, Jarjour WN, Suzuki N, Nojima Y, Roubey RA, Mimura T, Yamada A, Hosoya T, Takaku F, Winfield JB. Autoantibodies to nucleolin in systemic lupus erythematosus and other diseases. J Immunol. 1991;146:2249-2252.

View Article Google Scholar

55. Valdez BC, Henning D, Busch RK, Srivastava M, Busch H. Immunodominant RNA recognition motifs of human nucleolin/C23. Mol Immunol. 1995;32:1207-1213.

View Article Google Scholar

56. Tuteja N, Huang NW, Skopac D, Tuteja R, Hrvatic S, Zhang J, Ponger S, Joself G, Faucher C, Amalric F. Human DNA helicase IV is nucleolin, an RNA helicase modulated by phosphorylation. Gene. 1995;160:143-148.

View Article Google Scholar

57. Tuteja N, Phan TN, Tuteja R, Ochem A, Falaschi A. Inhibition of DNA unwinding and ATPase activities of human DNA helicase II by chemotherapeutic agents. Biochem Biophys Res Commun. 1997;236:636-640.

View Article Google Scholar

58. Yang TH Tsai WH Lei HY Lai MY Chen DS Yeh NH Lee SC Purification and characterization of nucleolin and its identification as a transcription repressor Mol Cell Biol 19941460686074359133 10.1128/MCB.14.9.6068

59. Ugrinova I Monier K Ivaldi C Thiry M Storck S Mongelard F Bouvet P Inactivation of nucleolin leads to nucleolar disruption, cell cycle arrest and defects in centrosome duplication BMC Mol Biol 20078661976620 10.1186/1471-2199-8-66

60. Gorsler T Murzik U Ulbricht T Hentschel J Hemmerich P Melle C DNA damage-induced translocation of S100A11 into the nucleus regulates cell proliferation BMC Cell Biol 2010 11 1003018407 10.1186/1471-2121-11-100 